\title{
La revista Alma Española: Literatura y Política en la Generación del $98^{1}$
}

\author{
M. ${ }^{a}$ Asunción Mora Martínez \\ Universidad de Alicante
}

\begin{abstract}
Alma Española, como cualquier otra revista de la época, es una revista clave para captar la sensibilidad vital de la España radical y reformadora en un momento de aguda crisis política e intelectual. Esta revista desempeñó un papel fundamental en la vida cultural de la época: unificar y abrir caminos a la juventud literaria y periodística, hoy adscribible a la «Generación del 98». El desastre de 1898 fue todavía el punto de partida de toda discusión acerca del «problema nacional». Sus colaboradores aspiran a que esta revista sirva de lazo de unión a todos aquellos escritores que se preocupen seriamente del porvenir deEspaña. Quieren que esta revista no sea un haz de artículos sino un conjunto armonizado de anhelos personales y, a su vez, que represente un estado de opinión, deseo que vamos a ver realizado a lo largo de este trabajo.
\end{abstract}

1 Este artículo es síntesis de la tercera parte de la Memoria de Licenciatura La revista «Alma Española»: Literatura y Política de la Generación del 98, presentada en la Facultad de Filosofía y Letras de la Universidad de Alicante en 8 de julio de 1985 . En este trabajo sólo vamos a exponer o a relacionar aquellos artículos de Alma Española con fondo sociopolítico. Los artículos que nos reflejan el panorama cultural de la época los estudiaremos en otro momento. 
Al leer los veintitrés números de Alma Española - publicados entre el 8 de noviembre de 1903 y el 30 de abril de 1904- nos damos cuenta, en primer lugar, de que sus colaboradores no querían dejar sin tocar ningún aspecto de la vida nacional y cultural. Si analizamos temáticamente sus artículos conoceremos de manera exhaustiva la aguda crisis política e intelectual que sufría España, crisis que vivieron y plasmaron en sus escritos los jóvenes del 98. Por otra parte, no pasa desapercibído su tono radical, su postura reformadora y el ansia de sus colaboradores de formar una España nueva. La mayoría de sus colaboradores desean encontrar la solución para la grave crisis política, social, económica y cultural que atraviesa la nación. Para ello estudiarán minuciosamente los diversos aspectos de la España que les ha tocado vivir, para curarla de todos sus males.

Los temas que aparecen en los artículos de Alma Española son abundantes pero, como demostraremos a continuación, irradian del mismo propósito de la revista: la regeneración de España. En la mayoría de ellos se refleja la situación sociopolítica de la época debido al rechazo que sienten hacia ésta los escritores que colaboran en la revista, rechazo más o menos radical de la literatura, arte, valores, instituciones políticas y económicas de la sociedad de la Restauración.

Así, el objetivo que perseguimos en este trabajo es dar a conocer la aguda crisis política e intelectual que sufría España, crisis que vivieron y plasmaron en sus escritos los jóvenes del 98. Por otra parte, dada la evidencia de su tono radical, su postura reformadora y el ansia de sus colaboradores de formar una España nueva, vamos a recomponer el programa de regeneración nacional manifiesto en los artículos de Alma Española.

\section{Política y Sociología.}

El denominador común de los escritores de Alma Española es, como ya hemos advertido, la disconformidad con la situación de la España que contemplan. Todo lo que estaba relacionado con la sociedad de la Restauración estaba para ellos corrompido. Para sanear la vida de la nación en todos los aspectos, los colaboradores de Alma Española acordaron que España debía cambiar sus estructuras empezando por la constitución interior y siguiendo luego por la renuncia o modificación de su espíritu tradicional. Para ello la revista acometió dos ensayos muy interesantes. El primero planteaba, cara a la opinión nacional, el magno problema que contenía esta pregunta: «¿A su juicio, dónde 
está el porvenir y cuál debe ser la base del engrandecimiento de España?». Por esta encuesta lo mismo desfilaron españoles que tenían ya su nombre consagrado en la política - Francisco Romero Robledo, Antonio Maura, Silvela, Salmerón-, como en la ciencia - Santiago Ramón y Cajal-, en la literatura — Vicente Blasco Ibáñez, Emilia Pardo Bazán, Unamuno-, en el periodismo, etc.

Una de las respuestas más interesantes - pues su contenido resume todas las demás - es la del General López Domínguez (AE, II, 15 noviembre 1903,2 ). Su programa regenerativo se basa en la instrucción general del pueblo, el desarrollo de la riqueza nacional y de las obras públicas, una administración inteligente y honrada, la reorganización de las fuerzas de mar y tierra y una alianza con Portugal y América Latina. Todas estas soluciones, plasmadas y desarrolladas en los distintos artículos de Alma Española, conducirán a España a su engrandecimiento.

En cuanto al segundo ensayo, España era, para Alma Española, una unidad fecunda nacida de una variedad armonizada. Debido a ello, la revista emprendió el desmenuzamiento de esta idea encomendando a un grupo de escritores la tarea de interpretar, sobre el fondo de la unidad indestructible de la Patria común, las diferentes «almas regionales».

Miguel de los Santos Oliver al describirnos el «alma mallorquina ${ }^{2}{ }^{2}$ nos pone al descubierto que España con un ideal nuevo de vida europea puede seducir definitivamente a Mallorca y alejarla de la amenaza catalana. Mallorca, al carecer de sentimiento de patria, está a disposición de cualquier tendencia que quiera seducirla ¡Quién mejor que España, la nueva España, para ello!

José Nogales en la descripción que realiza sobre el «alma andaluza) ${ }^{3}$ manifiesta la contradicción existente entre el medio físico de Andalucía, que invita a la acción, y el alma, que se amodorra en el desencanto heredado, en la inercia, en la quietud. Los andaluces protestan porque no pueden crear nada. El Estado aumenta los impuestos y Andalucía es explotada por los extranjeros y por los mismos castellanos.

2 Véase Miguel de los Santos Oliver, «El alma mallorquina», ( $A E$, VI 29 noviembre 1903, 1-3).

3 Véase José Nogales, «El alma andaluza» (AE, V, 6 diciembre 1903, 1-2). 
José Nogales lamenta que nadie haga nada por restablecer el equilibrio de la vida andaluza, a pesar de que las protestas aumentan día a día.

En «Panteísmo asturiano» (AE, VII, 20 diciembre 1903, 10-11), Ramón Pérez de Ayala nos dice que para él no hay un «alma española» puesto que «darle un alma de una pieza a la nación, es tan aventurado como colgarle al Estado una religión positiva y única». Seguidamente nos describe el espíritu del pueblo asturiano. Éste brota del viejo labriego asturiano que, por encima de todo, es «panteísta, íntimamente religioso para con la madre tierra, es su esclavo, no con la servidumbre necesaria del siervo de la gleba; sino con el renunciamiento del amante a su querida».

Francisco Acebal completa la descripción ${ }^{4}$. Ninguna región española, nos dice, avanza con tanta independencia o tanto desdén hacia el poder central, absorbente y pegajoso, como la asturiana. Asturias se halla tan mal gobernada como las colonias pero vive por sí misma con tal fuerza que para nada le afecta la marcha de la rueda central.

En esta región la idealidad no existe, por lo que este Principado no existe para la España estética. «Asturias necesita en los umbrales del siglo XX otro Jovellanos como el que tuvo en los umbrales del siglo $\mathrm{XIX} »$, nos dice.

Miguel de Unamuno es el encargado de describirnos el «alma vasca» ${ }^{5}$. Ésta se caracteriza por su rudeza, por ser impetuosa, autoritaria, a la vez que independiente. Es su pueblo de ágil, activa y silenciosa inteligencia. Tiene un espíritu reaccionario, conservador en el mejor sentido. El pueblo vasco es emprendedor y activo; toma el mundo en serio. «El día que pierda la timidez, cobre conciencia de sí y aprenda a hablar en un idioma de cultura, os aseguro que tendréis que oírle, sobre todo si descubre su hondo sentimiento de vida: su religión propia».

La descripción del «alma valenciana» ${ }^{6}$ es llevada a cabo por Vicente Blasco Ibáñez. Parece ser la más realista de todo el conjunto. Describe de forma ordenada la vida de la sociedad valenciana, tanto rural

Véase Francisco Acebal, «Alma asturiana» (AE, IX, 3 enero 1904, 2-4).

5 Véase Miguel de Unamuno, «El alma vasca» (AE, X, 10 enero 1904, 3-5).

6

Véase Vicente Blasco Ibáñez, «El alma valenciana» (AE, XI, 17 enero 1904, 10-12). 
como urbana, destacándose claramente las ideas republicanas de Blasco Ibáñez.

Juan Maragall describe el «alma catalana» (AE, XII, 24 enero 1904, 6). Resalta en ella, sobre todo, el ansia de libertad. De igual modo, Manuel Feliu describe el «alma riojana» ( $A E$, XIII, 31 enero 1904, 10-11), Rodrigo de Acuña el «alma granadina» (AE, XIV, 7 febrero 1904, 4-6), Antonio Royo Villanova el «alma aragonesa» (AE, XVI, 21 febrero 1904, 1-2) y Vicente Medina el «alma murciana» (AE, XX, 27 marzo 1904, 8).

Con todos estos artículos queda claro que España era una unidad fecunda nacida de una variedad armonizada, y el «alma española», la suma de todas las «almas» dispersas por el mapa nacional. Así, el «alma española» tendría un ideal propio asequible, realizable, orgullo de origen, espíritu colectivo y resistente al instinto gregario, ágil inteligencia y espíritu religioso y protestante a la vez. Sería ruda, impetuosa, autoritaria, tímida, laboriosa, emprendedora, tenaz, alegre, esperanzadora y poco contemplativa, obstinada, paciente, infatigable, poco hipócrita, poco idealista, violenta y rápida en sus decisiones, humilde, pura, buena y sencilla.

Como ya hemos expuesto lo que necesita España para su regeneración física y moral, vamos a estudiar, seguidamente, el contenido que encierran los artículos sociopolíticos de Alma Española.

\section{a) Protesta contra el sistema político de la Restauración.}

En los primeros años del nuevo siglo se configuran plenamente las fuerzas y las figuras políticas que van a protagonizar cuatro décadas críticas de la vida política española. Al mismo tiempo que desaparecen o se eclipsan las primeras figuras de los periódos de la Restauración y la Regencia, ascienden al primer plano hombres políticos hasta entonces inéditos o en plano secundario. Desaparecidos Cánovas y Sagasta, los partidos turnantes revisan sus programa; se renuevan las corrientes ideológico-políticas y emergen nuevos partidos, nuevos grupos de presión; el comportamiento electoral de los ciudadanos acusa cambios clasistas o regionales de profundo alcance. El país se divide en torno a la cuestión religiosa. El Ejército comienza a sentirse incómodo dentro de la neutralidad política donde fue colocado en la Restauración por Cánovas. 
Ante la desaparición de Cánovas y Sagasta, los Partidos turnantes parecía que se hubiesen quedado huérfanos cuando, en realidad, lo que ocurría era que la excesiva tutela de una larga jefatura había quemado las más importantes energías de la segunda fila. Con Cánovas y Sagasta, los partidos históricos se mantendrán unidos. Desaparecidos los líderes, todo será discutible en el seno de los partidos y las fracciones partidistas, por tanto, serán la causa de la brevedad de los Gobiernos. Muchos fallos se acumularán en estos gobiernos tan inestables.

La nueva generación de escritores que aparece en Alma Española se rebelará contra la herencia política legada por los hombres de la Restauración: el sistema parlamentario, la situación política y los políticos del momento.

Prueba de ello es el artículo de Eduardo Benot titulado «Gobiernos que no gobiernan»:

El alma española considera como transitorio el estado de cosas actual y quiere una revolución que ponga fin a la interinidad en que el país se encuentra, que es una serie inacabable de perturbaciones, tiranías y represalias, porque las tiranías traen necesariamente la revolución ${ }^{7}$.

El alma española necesita para poder vivir el desarrollo íntegro de sus facultades físicas, intelectuales y morales y no quiere la vida sin la inviolabilidad del hogar, sin la libertad de la palabra, de Prensa, de trabajo, de conciencia, de reunión. España quiere respirar la atmósfera de la invención; quiere un sistema de enseñanza que nutra los entendimientos de la savia del porvenir. En suma, quiere un Gobierno que no ponga grillos a la enseñanza, y será ingobernable hasta que tal consiga ${ }^{8}$.

España vive en «interinidad» ${ }^{9}$. España, desmayada e inerte, contempla cómo se disputan sus hombres de Estado la dirección de los asuntos públicos, no como mandatarios o servidores suyos, sino a modo de

7 Véase Eduardo Benot, «Gobiernos que no gobiernan» (AE, III, 22 noviembre 1903, 1-2). En este artículo se analizan las causas por las que se llega a afirmar que España es una nación muerta, ingobernable y sin esperanza.

$8 \quad$ Para la creación de la educación nacional se fundó en 1876 el Instituto Escuela de Educación Libre de Enseñanza, inspirada en las ideas pedagógicas modernas. A pesar de sus buenos profesores y sus muchas ventajas respecto a la educación, el ingreso en ellas es lento y muy pobre. Véase Manuel Carretero, «La Institución Libre de Enseñanza», ( $A E$, VII, 20 diciembre 1903, 2-3).

9 Véase Anónimo, «La fotografía indiscreta» (AE, XVIII, 13 marzo 1904, 10). 
«gestores oficiosos de un negocio abandonado por su legítimo dueño» y en el cual éste no toma responsabilidad ni pone cuidado. Todos desean un cargo relevante pero, una vez conseguido, no se hacen responsables de él.

La responsabilidad ante determinados hechos o cargos - tanto de los españoles en general como de los hombres de Estado, en particularno existe en la España de la Restauración. Nadie se hace responsable de lo ocurrido. El símbolo y la encarnación de España es Don Nadie; éste lo es todo en España ${ }^{10}$. El rige nuestros destinos, está al frente de todas nuestras manifestaciones intelectuales, físicas y morales. «Aquí 'Nadie' gobierna; 'Nadie' administra justicia; 'Nadie' fomenta la cultura pública; 'Nadie' protege la agricultura y la industria; 'Nadie' garantiza los derechos del pueblo [...]. Aquí, cuando acaece algo bueno, a 'Nadie' se debe, y en justa reciprocidad, cuando ocurre algo malo, a 'Nadie' se le echa la culpa». En sus manos está el porvenir de la nación española ya que él es el responsable de la pérdida de las colonias y él mismo el que nos ha prometido la regeneración.

De los males e imperfecciones en que abunda el sistema parlamentario hablan con frecuencia nuestros políticos, tanto los partidarios como los adversarios del régimen. Su labor crítica ayudará a conseguir la soñada transformación positiva ". Ésta se realizará por medio de la «libre emisión del voto» y libre acción de las Cortes». Se trata de ejercer la libertad tanto los electores como los legisladores y Gobiernos. Pero no existe la fe en los resultados de la libertad y de ahí el olvido de toda educación política, el abandono de los derechos electorales y las fáciles elaboraciones de una opinión mentida.

Las elecciones, como bien sabemos, son la gran farsa nacional ${ }^{12}$. El caciquismo corroe la fe de los electores en el buen funcionamiento del aparato electoral. Los políticos, gracias al caciquismo, son elegidos a voluntad del ministro de la Gobernación. Por todo ello, los electores se muestran indiferentes e impotentes para luchar contra tan enmarañado sistema parlamentario.

10 Véase Antonio Martínez Viérgol, «El sastre del Campillo», «S. E. Don Nadie», (AE, XVIII, 13 marzo 1904, 10).

11 Véase Adolfo Pons Umbert, «Parlamentarismo», ( $A E, \mathrm{XV}, 14$ febrero 1904, 14-15).

12 En los versos de Juan Pérez Zúñiga titulados «Micifuz y Zapirón» (AE, II, 15 noviembre 1903,10$)$ se nos cuenta la historia de un hombre que votó en varios distritos con el mismo nombre que vio impreso en un panteón el que escribe los versos el día de difuntos. 
Ciertas realidades políticas, expuestas con humor e ironía, las encontramos en los versos de Luis de Tapia que aparecen con el nombre de «Pimiento molido» (AE, V, 6 diciembre 1903, 8). En ellos se desea que el pueblo español deje su papel de espectador, se lance a la acción, haga caer al cacique y elija a los ministros que mejor sepan defender los intereses nacionales.

Es frecuente encontrar en los artículos de Alma Española la comparación entre el pasado - con grandes esperanzas, grandes conquistas y asombrosos hechos- y el oscuro futuro lleno de sombras y fantasmas negros ${ }^{13}$.

La generación actual, que vive en época de transición, no puede disfrutar ni de lo ilusorio del pasado, ni de lo positivo aún por venir. Ernesto López, «Claudio Frollo», en la «Juventud actual» (AE, VI, 6 diciembre 1903, 7-8) estudia la presente generación. Ésta, o es groseramente utilitaria y sólo usa su talento para llenarse los bolsillos de duros o se pone a pensar en el problema de mañana, en el conflicto obrero, o en los graves problemas económicos. La situación sociopolítica en que se halla España hace que la juventud piense en estas cosas.

La relación de los sucesos políticos del período que estamos estudiando los podemos hallar en unos versos de Luis de Tapia, «Pimiento molido» ( $A E$, III, 22 noviembre 1903, 4). La juventud no hace nada para solucionar los males de España:

\footnotetext{
Adorada patria mía, ¿cómo han de cesar tus males, si los jóvenes del día son casi todos «liliales» que coleccionan postales y rezan la letanía? ...
}

Por otra parte, los «serios fundamentos», base de esta sociedad, están muy anticuados. Las leyes — hasta la del «Descanso dominical»y los derechos promulgados le dan risa. Menciona la Asamblea del Partido Liberal, celebrada el 15 de noviembre para elegir nuevo jefe. Califica a Vega de Armijo de genio de todos los demonios. Se mofa de $\mathrm{La}$ Cierva y disfraza a Canalejas de Amadís colgándose en su cinto la guerra de Melilla y en el sombrero el Tratado de París, dos hechos políti-

13 Con este mismo tema encontramos los artículos siguientes: Francisco Campos Campaña, «Viejos y jóvenes» (AE, XIII, 31 enero 1904, 10), Manuel Machado, «Bienaventurados los que ríen», (AE, XVI, 21 febrero 1904, 3) y Carlos Luis de Cuenca, «Los curanderos», (AE, I, 8 noviembre 1903, 11). 
cos que han mermado -y en el caso de Melilla, sigue y seguirá mermando- la población y la economía española.

El panorama político que se desarrolla entre 1903 y 1905 lo podemos leer, entre broma y broma, en los versos de Carlos Luis de Cuenca, «Mamá... política» (AE, IV, 29 noviembre 1904, 6). Se alude en ellos al caso de la señorita Ubao, protagonista de Electra de Galdós. Con ello se recuerda el escándalo anticlerical y político que suscitó el estreno de la obra galdosiana. En Mamá... política», el autor nos explica lo fácil que resulta obtener un cargo político. Sólo se necesita: «ejercer la abogacía, / que escriba artículos serios y hasta alguna poesía; / que frecuente el Ateneo; / que se haga un gabán de pieles; / que se deje de Bombillas y de juergas y jaleos / que hablen de él en los papeles». No importa si al joven en cuestión le falta aplomo y no tiene fijeza de opinión. Únicamente debe esforzarse en atinar al elegir al hombre público hacia el cual debe orientar su carrera política.

Como es de esperar, los colaboradores de Alma Española no sólo rechazan el sistema político vigente en esta época sino que también rechazan a los hombres de Estado. Luis Bonafoux, en el primer artículo que escribe para la revista ${ }^{14}$, lanza sus afilados dardos contra el Parlamento y los políticos de oficio, siendo su blanco preferido el Sr. Romero Robledo, Presidente del Congreso. En su opinión, el Congreso está formado de «histriones lúgubres y de mujerzuelas de caño sucio», «de personajes de cartón y caca». Protesta con gran sarcasmo contra el Sr. Romero Robledo pues siendo «el hombre más grande de la España mutilada» -el que hizo que miles de soldaditos fueran a morir a Cuba para sostener los monopolios de su política Conservadora-, ahora ha aparecido en el sitial más alto de España, en la "sedia gestatoria» del Congreso de los representantes del país; le han hecho amo de España. Bonafoux no puede admitir que siendo uno de los políticos responsables del Desastre colonial ahora sea Presidente del Congreso.

Como debemos suponer, no sólo los hombres de Estado eran los responsables del marasmo actual. También el pueblo con su indiferencia contribuyó a ello. En «La moraleja de las elecciones» (AE, II, 15 noviembre 1903, 9-10), Ramiro de Maeztu elogia a Maura porque intentó suprimir el caciquismo electoral, actitud que fue duramente criti-

14 Véase Luis Bonafoux, « ¡Honor a la pepitilla presidencial!», (AE, I, 8 noviembre $1903,2-3$ ). 
cada. Por este hecho, Maeztu reprocha al pueblo que no merece votar pues sólo lo hace contra los ministros que lo defienden.

En «Política en broma» ( $A E$, III, 22 noviembre 1903, 10), Antonio Palomero, «Gil Parrado», expone la dificultad en que se halla el Partido Liberal para encontrar un sucesor a Sagasta. Este se hacía respetar en el Partido. Todos le admiraban. Los aspirantes a líder del Partido los califica como «iHombrecillos!». En la Asamblea realizada para tal fin, ninguno de los aspirantes consiguió los dos tercios necesarios para obtener la jefatura. Este hecho será de gran significación para el futuro del partido. Muerto Sagasta, como ya hemos mencionado, todo serán discrepancias en el Partido Liberal.

Luis de Tapia en «Pimiento molido» (AE, IV, 29 noviembre 1903, 10) critica duramente al Partido Liberal. Protesta enérgicamente contra el hecho de que siempre son elegidos los mismos ministros. Ellos llevaron a España al Desastre y ellos mismos vuelven a conducir el timón de la Nación. Esta idea, como estamos comprobando, se repiten en muchos artículos. En ella radica el total rechazo del sistema político de la Restauración.

Uno de los muchos defectos de la política española es su falta de diplomacia. Luis Bonafoux nos lo pone de manifiesto en su crónica titulada «Desde París» (AE, IV, 29 noviembre 1903, 5). Trata de infeliz a Villaverde porque se ha dejado torear por Romero Robledo, entre otros muchos. «Estos estadistas a lo Villaverde podrán, todo lo más, ejercer de toreros en una corrida de bestias; pero ni para maletas sirven en una corrida de diplomáticos». En cualquier asunto de política exterior, a nuestros estadisticas nunca se les ha tenido en cuenta porque viven a oscuras. Pero, a pesar de ello, se recrean en su vanidad, siendo ésta una de las causas de la perdición de España.

Todos estos artículos nos ayudan a conocer el estado en que se encontraba la política, partidista y personalista, de 1903. Maura lucha contra la influencia de Silvela para ponerse al frente del Partido Conservador, jefatura que consigue después de su intervención en la sesión del 13 de noviembre en el Congreso. El 5 de diciembre Maura formará Gabinete. El Partido Liberal todavía carece de jefe a pesar de que Canalejas descollara entre los aspirantes.

Luis de Tapia en «El flamante Ministerio» ( $A E$, VI, 13 diciembre 1903, 6-7) ataca irónicamente a cada uno de los nuevos ministros su- 
brayando los rasgos más caricaturescos de su biografía y personalidad. En esta descripción, tan bien ilustrada por los dibujos de Karicato, se repiten continuamente los eternos defectos que el Consejo de Ministros tiene y debe corregir para el buen funcionamiento del sistema político.

Por su parte, Alejandro Sawa en «Los neo-conservadores» ( $A E$, VII, 27 diciembre 1903, 3-4) advierte al nuevo Gobierno de que si arrastran a España a la muerte, los españoles no les seguirán, reaccionarán y lucharán contra ellos, como ha ocurrido en otras ocasiones a lo largo de la Historia. En este mismo artículo, Alejandro Sawa relata, de manera un tanto subjetiva, la historia del Partido Conservador y de su jefe, Cánovas. Tacha a sus «sucedáneos» de «grandes chicuelos trágicos» que juegan a la política con dardos «sin reparar en que juegan sobre un tapete que no es sino la desgarrada y sanguinolienta piel del palpitante cuerpo nacional». Encarnan el reverso de las cuatro virtudes teologales. Así los define: «Maura, el escurridizo y altanero arrecife contra el que escupen sus rencores todas las olas de la política, es la Imprudencia; el padre Montaña es la Injusticia; Linares, el gimnasarca de Santiago de Cuba, es la Debilidad; Villaverde [...] la Soberbia, la Ira, y todos ellos el Desastre y la Muerte».

Silvela, anterior presidente del Congreso y jefe del partido Conservador es sustituido, como ya sabemos, por Maura. Baldomero Argente en «El caso Maura» (AE, XIV, 21 febrero 1904, 3-4) elogia a este político por la labor que quiere llevar a cabo de saneamiento de la conciencia política. Aunque Moret, Salmerón y Canalejas le aventajan en calidad política, Maura tiene la sinceridad y la fe, nos dice.

Hemos de advertir que se le elogia por la sinceridad que quiere dar a las elecciones, no por su labor política. Una crítica severa a esta última la tenemos en el artículo de Julio Burell titulado «Ante el orador» (AE, XVII, 6 marzo 1904, 3-4). Se confronta la personalidad de Cánovas con la de Maura, actual jefe de los Conservadores. Este último, como orador, aparece en un nivel inferior al primero.

Cánovas - por su caudal científico, literario, filosófico, etc.- era llamado por sus contemporáneos el «monstruo»y su fuerza adquirió caracteres de una superstición nacional, resultando insobornable e inaccesible. Maura - con la cultura fragmentaria e inconsciente del político o del periodista - es el monstruo de nuestros días al que ninguno de sus rivales teme. Todos le escuchan sin contradecirle. Sus victorias son 
fáciles y brillantes pero nunca cumple lo que promete. Si sigue así, por influjo de su política, el país caminará hacia la muerte.

En abril de 1904, Maura sufre un atentado en Barcelona. Los versos de Luis de Tapia y los dibujos de Karicato en «Música del viaje» ( $A E, \mathrm{XXI}, 16$ abril 1904,10 ) refieren este suceso protagonizado por un anarquista. «Federico Urales», en la gacetilla titulada «Raza sin vigor» (AE, XXI, 16 abril 1904, 9-10) responsabiliza a los intelectuales de los atentados terroristas por su insinceridad y cobardía para afrontarlos. En los periódicos éstos protestan «ruidosamente cuando se atenta contra un poderoso que puede ofrecer mercedes» pero no se enfrentan y condenan la génesis de tales atentados que no es otra que los precedimientos inquisitoriales que se han usado contra los trabajadores en las cárceles de España. Estos procedimientos han sido condenados por todos los pueblos cultos. Si hubieran sido combatidos y castigados a tiempo en España, «hubieran evitado la muerte de Cánovas y la herida de Maura».

Algunos escritores han apuntado que el único culpable de que las ideas anarquistas hayan buscado el pecho de Maura es la literatura. Contra ello se rebela Manuel Bueno ${ }^{15}$. Este escritor explica que la sugestión libresca no existe, que la difusión de las ideas anarquistas en los periódicos no lleva a fomentar actos terroristas, pues si así ocurriera «el Romancero castellano transformaríase de mero libro de recreo poético en incubadora de grandes capitanes». Con ello se afirma que el arte escrito no podrá ser nunca cómplice de la barbarie. Manuel Bueno desaprueba todo acto terrorista y como prueba de ello termina diciendo: «los pueblos decadentes y sin dignidad no merecen que nadie arriesgue su vida por privarles de un hombre político que los humilla y desprecia».

Miguel Sawa en la gacetilla «El chaleco de Maura» (AE, XXIII, 30 abril 1904, 10) nos cuenta que Maura en agradecimiento por haberse salvado del atentado del que fue víctima le envió el chaleco manchado de sangre a la «Mare de Deu de la Merced», desgarrado por el puñal de Miquel. Miguel Sawa acusa a estos hombres de que hacen del catolicismo una profesión y sugiere que debería de entregarle, en agradecimiento a la Virgen, como ofrenda la cartera de Presidente del Consejo

15 Véase Manuel Bueno, «La sugestión anarquista» (AE, XXII, 23 abril 1904, 2-3). 
de Ministros, renunciando para siempre de toda pompa política, y su milagroso chaleco a Sánchez Guerra.

Silvela, ex-jefe del Partido Conservador, tampoco se libra de las mordaces críticas. Contra él lanza sus dardos Luis López Ballesteros ${ }^{16}$. «Silvela es un muerto en perpetua resurrección». Hace más política y más vida pública ahora que nunca. Los Conservadores solicitan sus consejos y están pendientes de sus palabras. A través de un relato de un cuento de Droz intenta convencer a los Conservadores de que deben dar sepultura a Silvela porque «por ley natural, los muertos insepultos... molestan».

No todo son críticas acerbas contra los jefes de los partidos. Escasos son los elogios que la revista dedica a los prohombres políticos. La personalidad de Nicolás Salmerón, jefe del Partido Republicano, es elogiado por Luis Morote en el artículo titulado «Salmerón» (AE, XII, 24 enero 1904, 2-4). También encontramos expuesta la del jefe del Partido Liberal, Eugenio Montero Ríos, en «Juicios de Montero Ríos» ( $A E$, XIV, 7 febrero 1904, 2-3).

Un problema de gran relevancia encontramos sin solucionar en esta época. El alma española está sin las potencias necesarias para la compleja vida de la civilización moderna ${ }^{17}$. Desde el siglo XVII no hemos tenido ejército ni por mar ni por tierra. Por este motivo, las instituciones bélicas precisan cambios radicales en el fondo y en la forma, para lo cual hacen falta dos elementos: grandes hombres que infundan en el cuerpo social la vitalidad perdida o en suspenso, y un «cerebro militar» que con unidad de pensamiento y fijeza en la acción enderece la existencia nacional, torcida de su natural camino desde el siglo $\mathrm{XV}^{18}$.

El odio hacia la guerra - opinión compartida por muchos colaboradores de Alma Española y la mayoría de españoles- lo manifiesta Enrique Fahardo Fernández, «Fabián Vidal», en «Alrededor de un libro» (AE, XX, 27 marzo 1904, 11-12). Considera la guerra como un resto atávico de la época prehistórica. Comenta la obra de Burguete,

16 Véase Luis López Ballesteros, «Política. Los muertos» (AE, 13 marzo 1904, 8-10).

17 Véase Jenaro Alas, «Introito» ( $A E, \mathrm{VI}, 13$ diciembre 1903, 8).

18 Véase: Marcelo de Usera, «Ideales y Ejércitos» (AE, XV, 14 febrero 1904, 12) y Jenaro Alas, «Deficiencia primordial» (AE, VIII, 27 diciembre 1903, 8). 
Mi rebeldía. Es la obra de un rebelde que quiere modificar el concepto social y ético de las instituciones guerreras; quiere revolucionar la guerra convirtiéndola en arte de matar desde lejos y sin riesgo, en escuela de caracteres y en taller de almas.

Pocos son los artículos que podemos leer en Alma Española sobre la Monarquía. Estos tratan sobre la muerte de Isabel II y los viajes de propaganda política que realiza Alfonso XIII, guiado por Maura, a algunas ciudades de España.

No hubo ni pompas ni honras fúnebres para el cadáver de Isabel II a su llegada al Escorial. Sólo cuatro representantes del Gobierno le esperaban en el Monasterio. «Y nada más. Al dolor oficial le basta con eso ${ }^{19}$.

Los viajes que realiza el joven Rey en abril de 1904 a las ciudades de mayor conflictividad social son de propaganda política; muchos los consideran estériles para la patria y perjudiciales para la Monarquía. El viaje de Alfonso XIII y del Sr. Maura a Cataluña han servido según Ramiro de Maeztu ${ }^{20}$ - para que las clases ricas sean representadas por el Partido Conservador, pero Maeztu reflexiona y se pregunta ¿qué partido va a representar a los pobres?, ¿dónde está el hombre público capaz de formarlo? Para él éste es el verdadero problema que ha dejado en pie el viaje del Rey y de Maura a Cataluña.

Las damas barcelonesas son las que realmente disfrutaron con la visita del Rey a Cataluña. Corrían enronquecidas, empujándose y atropellándose para ver varias veces al joven monarca y su séquito. De todo ello nos informa Ramiro de Maeztu en «Los aplausos de las damas barcelonesas» ( $A E, \mathrm{XXI}, 16$ abril 1093, 5-6). El motivo de estos aplausos es que en Barcelona a pesar de ser una ciudad muy rica, muy bella, muy grande, las mujeres de los ricos fabricantes catalanes se mueren de aburrimiento en los magníficos palacios del ensanche. Hasta que no exista una sociedad cortesana en Barcelona «será inútil la propaganda catalanista porque a las mujeres se les irán los ojos detrás de las cosas madrileñas».

19 Sobre Isabel II podemos encontrar los siguientes artículos: Anónimo, «Isabel II» $(A E, X X I, 16$ abril 1904, 5) y Miguel Sawa, «Isabel II» $(A E, 23$ abril 1904, 9-10). En este último artículo se encuentra la frase citada.

20 Véase Ramiro de Maeztu, «Por Cataluña» (AE, XXIII, 30 abril 1904, 9-10). 
En «El rey en Andalucía» (AE, XXIII, 30 abril 1904, 2), artículo que aparece sin firmar, es donde claramente se manifiesta la estéril visita del Rey a los lugares de mayor conflictividad social. Este viaje carece de finalidad pues los Ministros y las Autoridades, de acuerdo con Ios caciques y los Gobiernos de estas provincias, pondrán especial empeño en que los vivas y las flores presenten al pueblo andaluz como un pueblo feliz, rebosante de entusiasmo y alegrías. Nadie podrá acercarse para exponerle los graves problemas que existen en Andalucía. Le enseñarán las industrias más adelantadas sin descubrirle que de los prodigios de la modernidad sólo se aprovechan unos cuantos y se convierten en motivo de opresión para los demás.

Efectuado el estudio sobre el sistema político de la Restauración y sus instituciones, nos falta exponer las denuncias que realizan los colaboradores de Alma Española contra la política exterior.

La protesta contra la política exterior que desarrollan nuestros hombres de Estado es unánime. Si fuéramos gobernados por políticos enérgicos y animados de verdadero patriotismo, reivindicarían nuestros derechos de soberanía en Ceuta y en Marruecos. Francisco Acebal en «Sin Marruecos...» (AE, XXII, 23 abril 1904, 5) pone de relieve lo sedienta de lucha que está siempre España contra el moro. Todo lo quiere solucionar a tiros mientras que los representantes del Gobierno francés, con una buena política de atracción, nos ha arrebatado el dominio de Marruecos.

Eduardo Lucini Callejo en «Defensa nacional. Ceuta. Lo que es y lo que debe ser» (AE, XVII, 6 marzo 1904, 1-3) denuncia el abandono político y económico que sufre Ceuta por parte del gobierno español. Sólo le interesa por la importancia estratégica que tiene con respecto a «la cuestión de Marruecos». Pone sobre aviso a los hombres de Estado para que formen la producción y el tráfico, pues aparte del interés material sería el medio más seguro de agrandar y consolidar nuestra influencia en Marruecos ${ }^{21}$.

No podemos dejar sin mencionar al tratar la política exterior algo que ya sabemos. La aguda crisis que sufre España en todos los órdenes

21 Este mismo autor en «La factoría de Río de Oro» (AE, XVI, 21 febrero 1904, 4-5) nos expone la situación en que se halla la factoría llamada «Villa Cisneros» en la Península de Río de Oro. 
de la vida nacional tiene su origen en el desastre colonial. Las protestas y denuncias son constantes. La opinión pública desea que los responsables expíen sus culpas.

En «Fiesta nacional» $(A E, \mathrm{XI}, 17$ enero 1904, 14) Jenaro Alas considera la doble hazaña llevada a cabo, el 1 de julio de 1898, por los defensores de El Caney y San Juan, espléndida e inútil. «Es todo un compendio de la historia militar nacional desde el principio de las imbéciles guerras de Flandes hasta el final de las no más discretas guerras coloniales». La política nacional, la política militar existente no sirvió para nada puesto que la guerra finalizó cuando ya estaban agotadas las fuerzas físicas y morales del país.

Todos hemos contribuido a la pérdida de Filipinas, nos dice W. E. Retana en «España en Filipinas. La verdad para todos» $(A E, X V$, 14 febrero 1904, 10-11). Después de introducirnos de lleno en la historia de la colonización española en Filipinas nos habla de la historia colonial. Reconoce, como otros muchos escritores y personajes públicos de la vida española, que fue un error político fusilar a Rizal aunque de todos modos España hubiera perdido las islas.

Ramiro de Maeztu también escribe sobre el Desastre colonial. En «Nozaleda y Rizal» ( $A E, \mathrm{X}, 10$ enero 1904, 10-12) se une a la protesta que en toda España ha suscitado el nombramiento del padre Nozaleda, exarzobispo de Manila en 1898, para la Sede de Valencia. Entraña al mismo tiempo una condenación del régimen frailuno y una apología a Rizal.

Es en el número siguiente de Alma Española, en el artículo titulado «La obra de los muertos» (AE, XI, 17 enero 1904, 13-14), donde Ramiro de Maeztu nos comunica que la actual campaña popular y periodística contra Nozaleda es el primer reto que opone España a los hombres del desastre. La opinión no ha permitido que Nozaleda tomara posesión de su cargo en la Sede de Valencia. Ahora le ha tocado a un fraile, nos dice Maeztu, pero, cuando el pueblo recobre fuerzas, uno a uno los responsables pagarán sus culpas.

En «Discutamos el desastre» (AE, XII, 24 enero 1904, 4-5-) Salvador Canals nos comunica que en el Congreso van a discutir largamente sobre el Desastre. Más graves que el mismo desastre fueron las dos manifestaciones de decadencia que se dieron en España con ocasión de éste - nos aclara-: las masas no lo sintieron, las clases no lo analizaron. 
Para que se analicen en el Congreso las causas que provocaron el desastre colonial es necesario repasar con crítica severa la política constitucional de la España liberalmente constituida desde la Revolución de Septiembre. Pero nada de esto se hará en el Congreso. Unos cuantos diputados se convertirán en fiscales de otros. Ahora bien, nadie tiene derecho en España, por virtud de sus propios aciertos, a erigirse en fiscal de los errores de los demás. Si todo el país analizara este tema se podría sacar algo positivo, la experiencia, pues « $i \mathrm{Ni}$ siquiera eso nos dejó el Desastre!».

La indiferencia con que acogió el pueblo de Madrid el desastre de Cavite es denunciada por Alejandro Sawa en "Crónica» (AE, XV, 14 febrero 1904, 4). El 2 de mayo de 1898, día en que se anunció públicamente la noticia, la gente se dirigió jubilosa a la Plaza de toros. Después, con razón, diría Silvela que España es un país sin pulso. Ni siquiera reaccionó cuando Costa, con un esfuerzo heroico, quiso despertarlo.

\section{b) Protesta contra la situación de la clase obrera.}

A pesar de que todas las constituciones políticas españolas del siglo XIX reconozcan la igualdad de todos los ciudadanos ante la ley, la estructura de la sociedad española es incoherente y desigual. Por un lado, se mantienen las situaciones de privilegio y diferenciación (la nobleza, el clero, el ejército) basadas en la tradición y el pasado histórico y, por otro, presionan y se van imponiendo los nuevos grupos de la sociedad burguesa, que tienen la fuerza económica y social, quedando marginada en un nivel inferior la burguesía y las clases medias. Por debajo de estos niveles y marginados de la estructura político-social se encuentran las masas de las clases populares integradas por obreros y jornaleros industriales y rurales.

La continuidad dinástica permite a la nobleza tradicional confirmarse como poder sustancial del «bloque del poder» político. Sin embargo, la aristocracia o la nobleza de sangre han muerto políticamente a manos de la democracia. De esta clase priviligiada queda un rico manantial para la novela y el cuento, pues «la aristocracia de nuestro siglo, la del talento, aventó sus cenizas con la reflexión y con la publici- 
dad», nos dice Cristóbal Castro en su artículo «Titulos y grandezas» (AE, VI, 13 diciembre 1903, 9) ${ }^{22}$.

En cuanto a la burguesía española, nos dice Manuel Bueno, «es ignorante, pacata y estacionaria» ${ }^{23}$. Ésta, al oscilar entre dos opuestas corrientes de ideas y sentimientos - la sobria educación castellana, de usos añejos y la que busca nuevas formas de divertirse-, da a la vida social elegante un tono de hipocresía que fatiga. Nadie se atreve a nada. No existe la menor preocupación estética. Ello se debe a que la mujer aristócrata o la mujer burguesa son incapaces de sentir lo bello; son ignorantes bajo su barniz de cultura ${ }^{24}$.

En Alma Española no se nos muestran las condiciones de vida tan privilegiadas en que viven las clases altas, por el contrario, se nos informa de las míseras condiciones en que viven y trabajan los obreros. Éstos recibían jornales de hambre; trabajaban en talleres de pésimas condiciones higiénicas; carecían de instrucción y de fórmulas de previsión social; realizaban jornadas de trabajo agotador, etc. Los colaboradores de Alma Española van a intentar enderezar y delatar la dolorosa y mísera vida de los obreros y las inquietudes impunes de los poderosos. Con artículos de escalofriante realidad intentarán paliar el abuso y la explotación que la sociedad capitalista hace de los obreros. Éste es el verdadero y único objetivo que pretenden: acabar con toda clase de injusticias sociales.

Antes de encontrar esa alma española que todos anhelan hace falta un cuerpo en que esa alma encarne; carecemos de él mientras la pobreza domine el organismo de los españoles ${ }^{25}$.

La miseria ataca directamente al cuerpo humano, lo martiriza sin

22 La decadencia de la aristocracia, clase social que simboliza a la España decaída y extenuada, la podemos ver también en los artículos: José Martínez Ruiz, «La farándula. Mariucha» (AE, II, 15 noviembre 1903, 4); Luis Gabaldón, «Caricatura de periodistas. En casa de los Marqueses) ( $A E$, IV 29 noviembre 1903, 8) y en Ramiro de Maeztu, «Los aplausos de las damas barcelonesas» (AE, XXI 16 abril 1904, 5-6).

23 Véase Manuel Bueno, «Crónica. El arte de vivir» (AE, VI, 13 diciembre 1903, 2).

24 Véase «Fabián Vidal, «Las mujeres y el arte», (AE, XXIII, 30 abril 1904, 7-8).

25 Véase Manuel M. Barroso, «AAlma española... ¿y el cuerpo?» $(A E, \mathrm{~V}, 6$ diciembre 1903, 11). 
compasión. La pobreza prolongada, la fatiga de un trabajo continuado, la mala alimentación después de ese trabajo diminuyen la fuerza humana, niegan al hombre la sensibilidad física y alteran su sensibilidad moral. Manuel M. Barroso nos dice que hemos de constituir sobre base sólida el organismo humano y para ello hemos de explotar a los que nos explotan. Hemos de exigirles que nos paguen nuestro trabajo para que podamos comer, vestir y ahorrar.

En el artículo de José M. Ruiz titulado «Crímenes españoles. El de Don Benito. Ambientes y personajes» (AE, III, 22 noviembre 1903, 8-9) se nos relata la historia de un crimen acaecido en un pueblo extremeño. En él se manifiesta de manera clara su rechazo contra las desigualdades económicas y los privilegios de las clases sociales altas.

Este crimen es histórico y sigue vivo, ochenta años después de haberse cometido, por el papel que desempeñó el pueblo; por los gritos, las demandas y las exigencias de la ciudad de Don Benito. Se habla del crimen de Don Benito, no de Inés María, porque fue la ciudad el auténtico protagonista del hecho ${ }^{26}$.

Carlos García de Paredes - «señorito hastiado e inactivo» que podemos haber visto en algún casino de pueblo- asesinó a Inés María Calderón y a su madre, doña Catalina Barragán, la madrugada del 19 de junio de 1902. Los detenidos por sospechas o pruebas fueron cinco. Sólo cuando aparezca el auténtico testigo del crimen - Tomás Alonso Camacho- se descubrirán los auténticos protagonistas.

El asesinato de Inés María y de su madre será el factor desencadenante de la movilización popular. Debajo estaban: la lucha soterrada de clases, el abuso secular de unos pocos, y las ansias de cambio y un espíritu revolucionario que ya empezaba a notarse en el ambiente. Contra todo ello se rebelará J. Martínez Ruiz y su generación.

Un artículo de escalofriante social es el de Joaquín Dicenta «En el fondo de la mina. Almadén» (AE, I, 8 noviembre 1903, 4-7). Expone las míseras condiciones en que se encuentran las minas de Almadén -y en general todas las de España- y la injusticia con que trata el Estado a sus obreros.

26 La explicación de los hechos acaecidos en el crimen de don Benito la podemos encontrar en: Augusto Martínez Olmedilla, Cien años y un día, Aguilar, Madrid, 1960 , pp. $280-285$. Su historia novelada la tenemos en el libro de José Manuel Vilabella, El crimen de don Benito, Eds. Albía, Espasa-Calpe, Madrid, 1983. 
Los mineros son criaturas «harapientas de traje, lívidas de piel, ruines de sangre, pobres de inteligencia, faltas de pan, ahitas de mercurio [...]; seres que tienen la obligación de morirse pronto para que la mina sigua viviendo; hombres a quienes se retribuye con avaricia y explota con largueza, rebaño miserable de españoles que se desangran y se inutilizan para que el Estado español satisfaga las codicia de un banquero judío». Así, el Estado español como patrono es criminal pero como administrador se deja engañar y explotar por Rothschild.

En los pueblos mineros no existe la menor noción de la disciplina social y religiosa. «Impera el vicio en todo su esplendor», nos dice «Semper Talis» en «Gritos del Alma» (AE, VIII, 27 diciembre 1903, 4-5). Los mineros están atontados por el tabaco y los efectos del alcohol, y por la lectura de papeles socialistas y anarquistas. Las hembras de los tiznados mineros dormitan en insanas viviendas, fumando pitillos y bebiendo cognac. Juegan a la baraja, se emborrachan y mascan tabaco cantando las dulzuras del amor libre, sin Dios, sin religión, sin hogar y sin la menor noción de educar hijos que amen a su patria. En este relato «reniegan de los honores de un progreso que así destruye los hermosos vínculos sociales del hogar».

Manuel Carretero en su artículo «Una fábrica de cuerdas de guitarra» ( $A E$, IX, 3 enero 1904, 6-7) comienza una serie de artículos cuyo objetivo consistirá en dar a conocer al público el abandono en que se encuentra la industria española.

Esta fábrica de cuerdas de guitarra es una de las dos o tres que hay en Madrid, pues en provincias no existe ninguna. Su exportación al extranjero y al resto de España es considerable. Ahora bien, las condiciones en que se trabaja son deplorables. Sus talleres están montados a la antigua, sin más aparatos por máquinas que unas cañas, dos o tres tornos y media docena de cubas rotas. Para llegar a estos talleres se ha de cruzar por patios de herrería sucios, pobres. La ganancia que se obtiene ha de dar para todo «menos para la construcción de un modesto edificio donde podría desarrollarse en mejores condiciones esta importante industria española».

En «Industrias. Una fábrica de trapos» ( $A E$, XII, 24 enero 1904, 11-12), nos dice que esta antigua casa vive y se desarrolla únicamente explotando los desperdicios de los hombres, y no fabrica nada. El trapero recoge los desperdicios de las casas (los trapos inservibles) los ven- 
de a la «fábrica» y en ella los clasifican, prensan, embalan, etc. Esta «fábrica» da trabajo diario a cincuenta o sesenta personas. Las ganacias no deben ser insignificantes si se comparan con otras industrias que necesitan para su explotación máquinas, local apropiado y grandes sueldos para el personal. En esta industria las únicas máquinas que hay son las mujeres que trabajan. Lo hacen a destajo delante de grandes montones de trapos sucios, con todas las inmundicias, infectados de microbios. Por esta tarea horrible ganan de ocho a diez reales. Además, la salud de estas mujeres ha de ser buena, inatacable por los microbios.

Otro artículo en que se denuncia el trabajo duro y penoso de la mujer es el de Práxedes Zancada «Las trabajadoras del muelle de Santander» ( $A E$, XVI, 21 febrero 1904, 11). En él se pone de manifiesto la abundante tarea que realizan las cargadoras y descargadoras del muelle de Santander. Durante nueve o diez horas llevan sobre sus cabezas cestas de peso considerable por sólo ocho o nueve reales, insuficientes para las necesidades de la vida.

Ante estas deficientes condiciones de trabajo, los obreros se manifiestan constantemente contra sus patronos. Es época de huelgas: Barcelona, Bilbao, Tarragona y Jerez son los escenarios típicos de ellas ${ }^{27}$.

La injusticia social ocupa, como estamos comprobando, un lugar muy importante en las páginas de Alma Española. Francisco Acebal en su gacetilla «El buen juez» ( $A E, \mathrm{XX}, 27$ marzo 1904, 13-14) opina que a la magistratura le falta cierta flexibilidad humana, adaptarse un poco a las circunstancias. Expone el caso de un juez italiano que absolvió a una «puttana». Fue acusada de provocar y seducir a un hombre en la calle. Este juez alegó que también las señoras y señoritas en los salones y en los teatros provocan con sus miradas, sus sonrisas y paseos. «La justicia debe ser igual para todos y no servir para condenar a los pobres que hacen por necesidad lo que los ricos hacen por vicio».

Joaquín Costa colabora en Alma Española con su artículo «El pueblo y la propiedad territorial». (Ideas revolucionarias de antiguos gu-

27 Véase el artículo de Ramiro de Maeztu «Bilbao íntimo. Sigue el conflicto» ( $A E$, I, 8 noviembre $1903,7-8$ ). En él nos dice que para que cese el conflicto en Bilbao es preciso que los intelectuales prediquen la paz social y el olvido del pasado. Podrían representar a los obreros pero éstos ni los escuchan. «A Bilbao sólo le llevará a la paz la misma guerra», acaba diciéndonos Maeztu. 
bernamentales)», ( $A E, X, 10$ enero 1904, 6-10). En él se nos informa de los orígenes históricos de la propiedad territorial. Las leyes de la desamortización han sustraído a las clases menesterosas enormes patrimonios que componen la mayor parte de la riqueza territorial de la Península. Ello no es justo pues es sólo el pueblo en que en la guerra tiene la obligación de rescatar a la patria su personalidad y su soberanía. Por ello, sólo él debería gozar de su propiedad territorial pues sólo él la defiende con su vida.

En «Dinero» $(A E, I V, 29$ noviembre 1903, 4-5), Joaquín Dicenta rechaza el papel de la usura en la sociedad moderna. «Cuando la usura es pequeña y débil, devora una familia; cuando engorda y crece, se traga un país». Sólo tiene un propósito la usura, amontonar dinero. Es la consecuencia inevitable de un estado social en que todo se rinde, se sacrifica y se entrega a la idolatría del oro. «El oro es el Dios de las sociedades modernas. Poseer oro significa disponer de todo».

Entre los que se indignan ante la usura y los usureros están tanto los patronos, que prensan la carne de los trabajadores, como los soberanos, que compran y venden la carne de un país. La usura de éstos es más execrable. Mientras los prestamistas usurean con prendas materiales, los otros lo hacen con prendas morales fabricadas por la Naturaleza: hipotecan despiadadamente sentimientos e ideas, sacrifican el ansia del oro y del poder, la independencia de los hombres y el porvenir de las humanidades.

Manuel Carretero en «Los figones de Madrid» (AE, X, 10 enero $1904,14)$ analiza los menús atendiendo a las distintas clases sociales. Los burgueses y gente adinerada sólo comen hasta el hartazgo en las Pascuas y cuando les invitan a un banquete. Excepto en esas fechas, se aprecia en sus «menús» una economía censurable.

El pueblo bajo, el explotado, come un cocido de garbanzos, una sopa sin sustancia, unas tiras de estropajo y un raquítico trozo de tortilla, por principio. Después trabaja catorce horas porque precisa tener dos destinos para alimentar a los suyos. Pero aún hay gente en peores condiciones: los que comen en la tienda-Asilo. Estos devoran sin remilgos todo lo que le sirven en el plato y, a pesar de sus penas, están contentos.

Otros ni siquiera tienen los diez céntimos para comer, luego, el pueblo bajo, el que come cocido, debe estar contento de sus condiciones, 
afirma irónicamente Manuel Carretero.

La condena del hombre es tener que trabajar para comer, pero si no hay trabajo no hay pan y la falta de pan lleva a la revolución. Miguel Sawa en «Ganarás el pan...» (AE, XVIII, 13 marzo 1904, 14) nos informa de que el pueblo de Valladolid se ha amotinado pidiendo pan y trabajo. Si este problema no se solventa, la cuestión social nunca dejará de existir.

En «El saber de la miseria» (AE, VI, 13 diciembre 1903, 4-5), Manuel Machado denuncia el estado en que se encuentra en la calle la miseria humana. Un montón de criaturas humanas duermen, unas sobre otras, en los portales de la calle Mayor. Este montón de carne humana que sufre hambre y frío se siente feliz de poder sumar toda su miseria y su calor animal para defenderse del invierno. Se disputan los lugares donde menos frio hace. Pero las autoridades, celosas del ornato público los levantan y los echan a dormir al campo, a la cárcel o al hospital. Nosotros nada sabemos de la caridad humana pero los que padecen hambre y frío, sí saben de la miseria, nos viene a decir Manuel Machado.

Manuel Carretero en una serie de artículos que titula «Los Condenados» pide apoyo para que se solucione el problema social. En «Los Condenados. La tienda-Asilo» (AE, XIII, 31 enero 1904, 12-13) nos pone de manifiesto que poderosos propietarios de la calle Ferraz amenazan con la pronta desaparición de la hermosa obra del comedor del distrito de Palacio. La tienda-Asilo está en unos solares del Ayuntamiento que para nada sirven, pero a algunos ricos les molesta que al mirar enfrente se encuentren la triste y agonizante hilera de fantasmas sucios, malvestidos y hambrientos. Manuel Carretero brinda la solución de este asunto a las Cortes para que, al fin, hagan un bien por la patria y sus desgraciados habitantes.

La humanidad está completamente perdida y avanza que es un prodigio en sus abominables y fieros sentimientos. En «Los niños abandonados» (AE, XIV, 7 febrero 1904, 12-14), Manuel Carretero nos da cuenta de que el amor de los padres por los hijos es hoy muy difícil de encontrar $^{28}$. El cariño paternal se está convirtiendo en un mito y algunos

28 Véase también «En el tormento» (AE, XIII, 31 enero 1904, 14). En estos versos Vicente Medina denuncia la exportación de una niña en el circo. Trabaja en el trapecio sacudida por el aplauso del insaciable público que le pide más de lo que sus posibilidades físicas le permiten. 
padres creen que ya han hecho suficiente trayendo a sus hijos al mundo, y no los aman, ni los educan y menos los alimentan. Luego, estos hijos los mirarán con indiferiencia y sólo amarán a los que les protegen y alimentan.

En «iPobre madre!» (AE, XVII 6 marzo 1904, 14) Vicente Medina nos expone el caso contrario: los padres que cuidan y miman a sus hijos con ilusión y luego, los hijos ya mayores, los desprecian, reniegan y se avergüenzan de ellos.

El feminismo era una de las cuestiones palpitantes del momento, aún más fuera de España, y Alma Española dedica bastante sitio a la mujer, su educación y su posición social.

La relación familiar del hombre y mujer es analizada por Joaquín Dicenta en «Atavismo» (AE, XXI, 16 abril 1904, 2-3). Este escritor pide clemencia para la mujer española, descubriendo en el protagonista de un caso excepcional de sadismo matrimonial un símbolo sangriento del macho español en sus relaciones con la mujer.

El hombre español utiliza a su esposa para satisfacer sus apetitos de macho y sus aficiones de inquisidor a su antojo. La herencia musulmana sigue pesando sobre las relaciones familiares de hombre y mujer. No se considera a la mujer como compañera sino como esclava. Esto es debido, en parte, a la educación que recibe y, en parte, al moro que casi todo español lleva dentro. Los hombres no las miran como complementarias suyas, ni orgánica ni intelectualmente, sino como cosas queridas, amadas casi siempre, pero cosas al fin ${ }^{29}$.

Por otra parte, «Parsondes» en "La mujer» (AE, XXII, 23 abril $1904,2)$ nos dice que «el cuerpo de la mujer es el cebo deleitoso con que Dios engaña al hombre para perpetuar el dolor de la especie». Este subraya que cualquier político o neo cantará siempre las virtudes anímicas de la mujer pero ni uno solo se deleitará en modelar los hechizos de su cuerpo. «Es una triste manera de hacernos amar a las mujeres». Piensa que «la picardía lánguida de un 'couplet' de la Fornarina o la cadencia voluptuosa de uno de sus tangos, hacen más por el amor y por la vida que las heladas vocaciones de las mujeres sin cuerpo».

29 Esta misma idea sobre la mujer la vemos en Miguel Sawa, «Fraternidad humana», (AE, XVIII, 13 marzo 1904, 15). 
Como estamos observando, siempre se resaltan de la mujer sus rasgos físicos, nunca los morales e intelectuales. La princesa Luisa de Toscana representa el caso de la mujer que se rebela contra su destino perdiendo por ello su felicidad ${ }^{30}$. Ella no quería ser reina, deseaba vivir como cualquier mujer de la tierra. «Hasta llegó a hacerse público que en materias de arte la Princesa prefería Zola al Protocolo». Un día quedó rota la voluntad ensangrentada de la Princesa y huyó para siempre del palacio, de los suyos, del protocolo. Ahora quiere ver a sus hijos pero el palacio de Dresde no sabe de Piedad ni de Misericordia.

El tema de la prostitución aparece tratado en algunos artículos de Alma Española. En ellos no se censura a la mujer que desempeña este trabajo sino a la sociedad que la engendra. En «Los condenados. La Trata» (AE, XXIII, 30 abril 1904, 7), Manuel Carretero nos comunica que en las antiguas vías de Madrid, tristes y abandonadas, viven y trabajan miserablemente mujeres que toda su vida se han dedicado a la prostitución. Son ya viejas, están alcoholizadas y, de vez en cuando, hablan de sus miserables existencias. Cuando esto ocurre merecen ser oídas por todos los españoles, tanto padres de familias como hermanos y hombres del Gobierno.

En «La esclavitud blanca» (AE, XXIII, 30 abril 1904, 10) Bernaldo de Quirós también trata este tema. En este artículo expone el problema social que existe en España. El Estado debe evitar la trata de mujeres con un proyecto de reglamentación de la prostitución y no burocratizar el comercio infame. Con este reglamento de la prostitución se evitará el consecuente problema de sifilización nacional.

Francisco Acebal en «Las raíces del mal» (AE, XIX, 20 marzo 1904, 15) expone el problema de los beodos callejeros. Aquí, en España, cuando alguien se emborracha y va por la calle es recogido por la policía, se le aplica el tratamiento usual para que se le pase y lo devuelve al seno de la familia. En Londres, los beodos ya no pertenecen a la policía sino a la Ciencia, a la Medicina. Han fundado unos establecimientos para analizar las causas por las que se emborrachan. Una vez se conoce el mal, halladas las raíces, se mata. Pide que estos establecimientos también se funden en España. 
El portero es otro de los condenados por la sociedad ${ }^{31}$. Manuel Carretero nos da a conocer el caso de un portero que no encuentra trabajo en Madrid. Los burgueses, poseedores de hermosas fincas, les condenan a morirse de hambre en sitios infectos, donde, por su constante servicio les pagan de 25 a 100 céntimos al día. La vida de éstos es miserable. Debería formarse una sociedad de porteros y con la unión de todos ellos podría hacerse una huelga. Pero ello no es posible porque la junta directiva ya se ha comido varias veces lo recaudado al mes, por lo que los porteros ya no se dejarán convencer. Manuel Carretero pide en este artículo que se solucione este problema dándoles trabajo y mejores condiciones de vida.

La aspiración suprema de la mayoría de los españoles es ser empleado. Un empleo abre todas las puertas. Aquí en España no es nada un hombre sin destino. Por ello, todos los pasos de viejos y jóvenes se dirigen hacia la oficina. José de Siles en «Empleados y artistas» ( $A E$, XIII, 31 enero 1904, 7-8) nos dice que los padres mandan a sus hijos al colegio o a las Universidades no para que se hagan sabios sino para que, sea como fuere, triunfen en la batalla de la vida.

Nos presenta dos polos opuestos: el artista, el hombre independiente, y el oficinista, el hombre enjaulado. El hombre de iniciativas libres, el industrial, el artista, pocas veces recibe en sus comienzos protección de nadie. ${ }^{32}$. Y, sin embargo, estos hombres son los que empujan a un pueblo hacia la civilización, la prosperidad, la omnipotencia. «Son las fuentes creadoras, los manantiales puros y ricos, las abejas trabajadoras en la complicada maquinaria de las sociedades modernas»».

El empleado es todo lo contrario. Todos somos educados para empleados. Todos queremos un empleo con un sueldo seguro. Pero se origina una situación moral encogida, tímida, pasiva. Todo hombre es de-

31 Véase Manuel Carretero, «Los Condenados. El portero» ( $A E$, XXII, 23 abril 1904, 3-4).

32 Véase el artículo de Amós Salvador «Concurso de arquitectura. El nuevo edificio del Casino de Madrid» (AE, IX, 3 enero 1904, 12-13). En este artículo el Casino de Madrid convoca un concurso internacional para elegir los planos de su nueva casa. «Lo que hay que hacer —nos dice Amós Salvador- es proporcionar a los artistas españoles ocasiones y medios para que sea conocida su labor, ayudar a los que empiezan, evitar injustos acaparamientos de trabajo y educar el gusto del público para que no se vaya a buscar fuera lo malo, teniendo en casa lo mejor». 
pendiente de todo hombre. Así, las voluntades se hallan encadenadas formándose falanges de siervos sujetos al capricho del señor, del déspota, del cacique.

En España el arte es sinónimo de miseria. El empleado es emblema de posición asegurada. Esta irritante diferencia es una de las causas, indudablemente, de la decadencia moral e intelectual hacia la que ha venido arrastrándose nuestra patria.

Los periodistas, aunque se crea que su oficio es uno de los más productivos, alegres y descansados, viven en unas condiciones económicas cada día más duras. Luchan constantemente para ahuyentar la miseria. Los mejores periódicos defienden con sus plumas a los más menesterosos y oprimidos pero, se pregunta José López Pinillos ${ }^{33}$ en «El hambre de los periodistas» (AE, XIII, 31 enero 1904, 5) «¿cuándo pelearemos por nosotros pidiendo para nosotros?».

En el campo del periodismo existen diversas finalidades y orientaciones. Unos buscan el provecho político; otros, cierta popularidad mediana; intentan otros, cándidamente, forjarse un nombre literario. Todas estas posibilidades que ofrece el periodismo nos las expone José Martínes Ruiz en «Los libros. Dos palabras» (AE, XII, 24 enero 1904, 12-14). Opina que con el periodismo actual no puede hacerse ilusiones sobre estas cosas. Está muy lejos del ánimo de los periodistas de su generación conseguir ventajas políticas ya que sienten un profundo desdén por el mundo político; y en cuanto a la popularidad, si la consiguen, será bien a pesar suyo, bien irónicamente, pues se esfuerzan en que sus opiniones y juicios vayan contra las rutinas, contra los prejuicios y estupideces de la masa, que es la que da y quita las popularidades.

\section{La España nueva.}

En este apartado vamos a seleccionar aquellos artículos que nos aclaran las causas que han provocado - según los colaboradores de $A l$ ma Española - la decandencia de España para ocuparnos después de

33 Para conocer las tristes y escasas condiciones de vida de los periodistas véase el libro de Rafael Cansinos-Asséns, La novela de un literato. (Hombres-IdeasAnécdotas...), 1. (1882-1914), Alianza Tres, Madrid, 1982. 
aquellos que, de manera concreta, exponen las soluciones para su regeneración.

Francisco Acebal en «Gacetilla. Una respuesta» ( $A E, \mathrm{XXI}, 16$ abril $1904,9)$ nos informa acerca de una encuesta realizada en un semanario político francés, en la que se pregunta si está Francia en decadéncia. «Felices ¡ay! los pueblos que pueden tener el lujo de preguntar si están decadentes» - nos dice Francisco Acebal-, pues en España ni siquiera se plantea esta cuestión.

Los españoles se pasan la vida pidiendo «otra patria, otro siglo, otros hombres» y cada vez que se produce un cambio ministerial esperan con optimismo conseguirlo, pero continuan su vida con la misma rutina sin siquiera pensar en cambiar sus costumbres ${ }^{34}$. Es necesario que los españoles se rebelen contra su destino, que luchen por cambiar el rumbo que lleva la Nación, que se lancen a la acción para que no haya nuevos desastres.

El que España sea la escoria de Europa, y no el modelo del orbe, no es debido sólo a la ineptitud de sus gobernantes sino también a la de sus gobernados, pues todos son de la misma naturaleza ${ }^{35}$. La imponderable ociosidad de los españoles no deja de sorprender a cualquier extranjero. Los extranjeros reconocen las grandes cualidades de España para los cultivos y descubrimientos de minas de todos los metales y, también, la alta disposición de los españoles para hermosearla con sus artes, con las ciencias y con las fábricas, y se asombran de nuestro imprudente olvido y ningún cuidado en asuntos tan elevados y recomendables, que harían con su práctica a este país uno de los más florecientes del mundo. Si todo español instruido clamara con fervor contra cualquier descuido, vicio, omisión o defecto en que delinquiesen sus paisanos y les hicieren aborrecer la pereza, España saldría de su apatía. «Pero si los consejeros duermen, si los ministros sueñan y los magistrados descansan, cuando lo demás del reino delira, no puede sobrevenir a tal desmayo más que un torpe paroxismo».

España tiende a la decadencia, se nos dice en este artículo, porque tiene de menos agricultura, comercio, justicia, letrados, sabios, reali$10)$. 
dad, quintas, obras públicas, maestros buenos, virtud, etc., así como tiene de más contribuciones, jueces, leyes, negociantes viles, soberbia $\mathrm{y}$ vicios.

En el artículo titulado «Los luises» (AE, XXII, 23 abril 1904, 2) se nos dice que hemos quedado dos siglos atrás en el camino de la civilización y del progreso porque España es la única nación en que las asociaciones religiosas siguen dominando todavía la vida íntima del pueblo. Hay que instruirlo y enseñarle que estamos en el siglo de la discusión y del libre examen, el siglo en el que no se dobla la rodilla sino ante la razón. "No hay más que dos banderas, dos programas: el progreso o la reacción, la autonomía o la sujeción eclesiástica, la libertad de conciencia o la tiranía».

Anticlerical es también la gacetilla de Antonio Machado titulada «Trabajando para el porvenir» (AE, XIX, 20 marzo 1904, 14-15). La escribe con motivo de la construcción del edificio de los jesuitas en el Paseo del Cisne de Madrid. Su anticlericalismo se manifiesta cuando subraya que en España de aborrece a los curas porque son los únicos que han logrado sobrevivir.

Un cuento con signos de anticlericalismo es el que escribe Enrique de Mesa y titula «Cristo, solo» (AE, XXI, 16 abril 1904, 6-8). En él nos narra la venida de Cristo al mundo para comprobar cómo seguían los cristianos su doctrina. Jesús, ante el gentío que quería escucha sus palabras, se subió a un monte. Desde allí se dirigió primero a los sacerdotes. Les reprocha que no hayan seguido su ejemplo, que la cristiandad esté enferma, sus enseñanzas en el olvido, sus ovejas descarriadas y sus preceptos sin cumplir. También les dice que no les habló de poseer dinero y tienen los bolsillos llenos. Los sacerdotes ante tales culpas le volvieron la espalda y se marcharon. Conforme va hablando a la muchedumbre, los hipócritas se van marchando. Predica contra las riquezas acumuladas con lo cual los ricos le vuelven también la espalda y se marchan. Sólo quedó en la llanura la turba harapienta y miserable, los predilectos de Jesús, los cuales al ver que los ricos se marchaban, temiendo su reacción, les siguieron. Jesús les dijo que no podían servir a dos señores a la vez, a lo que los pobres respondieron que odiaban a los ricos pero son sus siervos. Ellos les dan los desperdicios de su mesa y los harapos con los que se cubren. La moraleja del cuento es que todos prefieren servir al Dinero y no a Dios. 
En «Alma desfallecida» (AE, XV, 14 febrero 1904, 6-7), artículo firmado por «Un Prójimo» se nos dice que hay que ser obediente, sumiso, humilde y resignado ante las leyes naturales y las morales pues unas implican a otras, van unidas.

Mientras la educación no se asiente sobre los principios de la resistencia activa a todo género de injusticias; mientras no cesen las predicaciones insensatas; mientras la gente no se convenza de que la moral que se predica da siempre los mismos resultados inútiles; «en una palabra, mientras no se reconozca que es más moral, más humano y más censillo exterminar a los lobos que aumenten los corderos, será completamente ocioso que Alma Española ande preguntando por el porvenir y la base del engrandecimiento de España», se nos dice claramente en este artículo.

Ahora vamos a ocuparnos de relacionar estos artículos que tratan sobre el propósito de nuestra revista: la regeneración de España. En el primer artículo de la revista tenemos expuesto de manera clara el tema de la regeneración de España. Benito Pérez Galdós en «Soñemos, alma, soñemos» ( $A E$, I, 8 noviembre 1903, 1-2) apunta que el primer paso que se debe dar es lanzarse a la acción. Hay que diferenciar lo que caduca y lo que germina en el alma nuestra. Todo ascetismo debe evitarse. Hemos de combatir la pobreza y trabajar metódicamente. Debemos oponernos enérgicamente al propósito que los ministros tienen de llevarnos a la muerte nacional. Antes, del Estado se esperaba todo. Ahora, el país se ha mirado en el espejo de su conciencia y se ha visto «compuesto de un rebaño de analfabetos conducido a la miseria por otro rebaño de abogados». En estos cincuenta años, el país ha crecido. «Aceptamos al Estado como administrador de lo nuestro, como regulador de la vida de relación; ya no lo queremos como principio vital, ni como fondista y posadero, y menos como nodriza».

Dos grandes aspiraciones descuellan en este artículo y en otros de Alma Española. Necesitamos instrucción para nuestros entendimientos y agua para nuestros campos. En nombre del bienestar público y de la belleza debemos inundar las estepas áridas.

Como el agua a los campos, es necesaria la educación a nuestros endurecidos entendimientos ${ }^{36}$. Hagamos cada cual dentro de su propia

36 La respuesta de Santiago Ramón y Cajal a la pregunta «¿A su juicio, dónde está 
esfera lo que sepamos y podamos. Rematemos cumplidamente lo que iniciemos, no dejemos nada a medias. «Cada cual en su puesto, cada cual en su obligación, con el propósito de cumplir estrictamente, será la redención única y posible, poniendo sobre todo el anhelo, la convicción firme de un vivir honrado y dichoso, en perfecta concordia con el bienestar y la honradez de los demás».

Ramiro de Maeztu en «Mariucha y el público» ( $A E$, II, 15 noviembre 1903,2 ) nos dice que se debe olvidar el pasado y trabajar sobre el presente. Como sabemos, el rechazo hacia el pasado, la tradición histórica, es unánime en los escritores noventayochistas.

Dos artículos en Alma Española nos informan acerca de los centros de instrucción que corresponden a las ideas regeneradoras de nuestra revista. El primero de ellos está firmado por Manuel Carretero y se titula «La Institución Libre de Enseñanza» ( $A E$, VII, 20 diciembre 1903, 2-3). En este artículo se hallan expuestas las numerosas ideas pedagógicas modernas y sus ventajas respecto a la educación aplicadas a este Instituto o Escuela de Educación Libre de Enseñanza. A pesar de todas sus ventajes - progreso en la enseñanza, buenos profesores, indudables aciertos pedagógicos- el ingreso en este centro educativo es lento, muy pobre, no pasa de unas modestísimas docenas de muchachos al año.

En «La secularización de las mujeres» (AE, XIII, 31 enero 1904, 2), Pío Baroja pide la educación para las mujeres, su colaboración activa en la vida social para darle una cohesión moral que no posee. El centro adecuado para ello es la «Asociación para la Enseñanza de la Mujer», ( $A E$, XI, 17 enero 1904, 8-9), C. Bernaldo de Quirós nos informa sobre este centro de educación general femenina y Escuela de algunas derivaciones profesionales, carrera de Comercio, de Institutrices, etc.

Con el tiempo, estas mujeres instruidas en el conocimiento que exige el vivir, irán saliendo transformadas en jóvenes animosas dispuestas a comprender el sentido serio y elevado de la vida. Sólo así se podrá detener la misoginia que hoy cunde, el temor y el desdén a la mujer, considerado un ser inferior y sospechoso.

el porvenir y cuál debe ser la base del engrandecimiento de España?» (AE, V, 6 diciembre 1903, 10) refleja la misma idea que aquí expone Benito Pérez Galdós: «Cultivar intensamente los yermos de nuestra tierra y de nuestro espíritu...». 
Francisco Giner de los Ríos colabora en Alma Española con el artículo titulado «Mi pesimismo» (AE, XIV, 7 febrero 1904, 3-4). En él, de manera concreta, expone lo que España necesita para salir de su postración. Califica de «divertido» el problema de nuestra presente situación nacional. Estamos mal pero no tanto como al Sr. Silvela le parece -nos dice. Necesitamos saber qué camino llevamos. No nos conviene una «dictadura» o un gobierno paternal, donde un grupo de hombres patriotas, sinceros y cultos, orienten por sí solos la vida nacional sin contar con el pueblo. Nos hace falta, en definitiva, una orientación firme y manos que la pongan en práctica.

Cristóbal de Castro en «El patriotismo del porvenir» ( $A E, \mathrm{XV}, 14$ febrero 1904, 4-5) denuncia el caciquismo que ejercen nuestros primates del Congreso en las Academias, y no hay Ateneo, sociedad científica o literaria donde éstos no hayan colocado a cualquier vulgar exsubsecretario. El caciquismo, que domina casi todos los aspectos de la vida nacional, hay que eliminarlo de raíz para que no infecte la España nueva que todos se esfuerzan en crear.

Miguel de Unamuno en «Guerra civil» (AE, 30 abril 1904, 2-3) apunta que España necesita una guerra para su regeneración. Mientras no se conquiste la perfecta libertad de conciencia, la igualdad perfecta y la fraternidad, no habrá paz. Para Miguel de Unamuno ${ }^{37}$ no habrá regeneración de España si no cambia el modo de concebir y de sentir la vida religiosa y la libertad de conciencia cristiana. Para el escritor vasco la regeneración de España sólo será posible si emana de una sacudida espiritual.

Es necesario en España un cambio de fondo y forma en las Instituciones bélicas ${ }^{38}$. El progreso del pueblo español estaría para Jenaro Alas - «Introito» (AE, VI, 13 diciembre 1903, 8)- en la formación de instituciones militares, pues carecemos de ejército de mar y de tierra.

Por su parte, Marcelo de Usera - «Ideales y ejércitos» $(A E, X V$, 14 febrero 1904, 14) - apunta que España necesita dos elementos prin-

37 Véase Miguel de Unamuno, «¿A su juicio, dónde está el porvenir y cuál debe ser la base del engrandecimiento de España?» $(A E, V, 6$ diciembre 1903, 10).

38 Véase el artículo de «Fabián Vidal» titulado «Alrededor de un libro» ( $A E, \mathrm{XX}$, 27 marzo 1904, 11-12). Burguete en su libro Mi rebeldía coincide con la idea expuesta por Jenaro Alas. Quiere modificar el concepto social y ético de las instituciones guerreras. 
cipales para su regeneración: grandes hombres que infundan energía a la 'sociedad y un cerebro militar que enderece la existencia militar ${ }^{39}$.

El problema económico también se plantea en Alma Española. Venancio Roca en «La inmortalidad de los grandes» (AE, XIX, 20 marzo $1920,10-11)$ nos dice que la crisis que padece el dinero nacional arranca de 1867. La depreciación de la moneda es constante a partir de este año. Después el Banco de España comenzó a fabricar billetes por lo que se unió el Tesoro al Banco de España, causa de nuestros males. La solución es romper esta unión, pero ni Villaverde ni el actual ministro de Hảcienda, Mr. de la Ville, se atreven a ello.

Para Ramiro de Maeztu la salvación de España está en entregarse a los fletes de Grandmontagne. Ello nos lo comunica en su artículo «Caricatura de periodista. La nueva savia» (AE, 3 enero 1904, 11).

J. B. Amorós en «El paletismo» (AE, 17 enero 1904, 7-8) señala que el sentido común reside en los paletos. La contabilidad campesina es mejor que la del Banco de España. Ellos, los paletos, pueden ser la salvación de España.

Para terminar este trabajo consideramos interesante recoger el programa regeneracionista que se nos muestra en los numerosos artículos de Alma Española. Es imprescindible para que España se regenere cambiar su estructura interior y modificar, después, su espíritu tradicional; eliminar el caciquismo deshonroso; impulsar la industria y la agricultura; cambiar el concepto de moral y eliminar la apatía del pueblo, lanzárlo a la acción.

Recordemos, por otra parte, que el porvenir y la base del engrandecimiento de España estarían en la instrucción general del pueblo sin distinción de sexos, en el trabajo, en una administración inteligente y honrada, en el desarrollo de la riqueza nacional y de las obras públicas, en la reorganización de las fuerzas de mar y tierra, en un gobierno fuerte que supere la política de partidos, en la verdadera libertad, en la eliminación de la tiranía religiosa, en la modificación de la conciencia colectiva de España y en la corrección de nuestra psicología como españoles.

Véase el artículo de Francisco Acebal, «Gacetillas. La guerra y la agricultura» (AE, XVIII, 13 marzo 1904, 14-15). Los generales de la guerra «boer» cultivan los campos que antes eran de batalla. En España nadie hace nada para remediar los males de la nación. 
Además, el alma española necesita para poder vivir el desarrollo integro de sus facultades físicas, intelectuales y morales y no quiere la vida sin la inviolabilidad del hogar, sin la libertad de palabra, de Prensa, de trabajo, sin la libertad de conciencia, sin la facultad de reunión, sin influencia en las decisiones de la justicia humana por medio del Jurado y sin la intervención en el gobierno de la sociedad por la soberanía del sufragio.

El pueblo se debe lanzar a la acción, hacer caer al cacique y elegir a los ministros que mejor sepan defender los intereses nacionales. El pueblo bajo debe creer sólo en el trabajo y luchar por la igualdad e independencia de éste.

Las instituciones bélicas precisan también cambios en la forma y en el fondo, para lo cual hacen falta dos elementos: grandes hombres que infundan en el cuerpo nacional la vitalidad perdida o en suspenso y un «cerebro militar» que con unidad de pensamiento y fijeza en la acción enderece la existencia nacional, torcida de su natural camino desde el siglo XV.

En Alma Española se advierte varias veces que no se debe esperar la salvación de España de tales o cuales fórmulas (socialistas, anarquistas, republicanas), ni de los políticos, sino de nuestros esfuerzos personales, aislados, persistentes, tenaces pero conducentes todos al ideal anhelado.

Desde el punto de vista artístico, el autor de cualquier obra literaria o artística- debe poner ésta al servicio de la verdad y de la propagación de los ideales contemporáneos. Se deben olvidar las grandezas pasadas y trabajar para construir un futuro sólido y consistente. $\mathrm{El}$ arte puro, dadas las circunstancias por las que atraviesa España, es inútil para la sociedad. Los artistas deben contribuir con su arte a la creación de una patria nueva poniendo en su obra un poco del espíritu que nos anima a todos. 